\title{
Oral selenate improves glucose homeostasis and partly reverses abnormal expression of liver glycolytic and gluconeogenic enzymes in diabetic rats
}

\author{
D.J.Becker ${ }^{1}$, B. Reul ${ }^{1}$, A.T. Ozcelikay ${ }^{1}$, J.P. Buchet ${ }^{2}$, J.-C.Henquin ${ }^{1}$, S.M. Brichard ${ }^{1}$ \\ ${ }^{1}$ Endocrinology and Metabolism Unit, Faculty of Medicine, University of Louvain, Brussels, Belgium \\ ${ }^{2}$ Industrial Toxicology Unit, Faculty of Medicine, University of Louvain, Brussels, Belgium
}

\begin{abstract}
Summary Selenium is a trace element that exerts certain insulin-like actions in vitro. In this study, we evaluated its in vivo effects on the glucose homeostasis of rats made diabetic and insulin-deficient by streptozotocin. $\mathrm{Na}_{2} \mathrm{SeO}_{4}$ was administered ad libitum in drinking water and/or food for 10 weeks. The elevated plasma glucose levels $(-25 \mathrm{mmol} / \mathrm{l})$ and glucosuria $(\sim 85 \mathrm{mmol} /$ day $)$ of untreated rats were decreased by 50 and $80 \%$, respectively, by selenate treatment. The beneficial effect of selenate was also evident during oral and intravenous glucose tolerance tests: the integrated glucose responses were decreased by $40-50 \%$ as compared to those in untreated rats. These effects were not due to an increase in plasma insulin levels. Compared to non-diabetic rats, pancreatic insulin reserves were reduced by more than $90 \%$ in treated and untreated diabetic rats. The hepatic activities and mRNA levels of two key glycolytic enzymes, glucokinase and L-type pyruvate kinase were blunted in diabetic rats. They increased $\sim$ two- to threefold after selenate treatment, to reach $40-75 \%$ of the values in non-diabetic rats. In contrast, elevated activity
\end{abstract}

and mRNA levels of the gluconeogenic enzyme, phosphoenolpyruvate carboxykinase, were reduced by $40-65 \%$ after selenate administration. Since selenate induced a moderate decrease in body weight due to an anorexigenic effect, we checked that there was no improvement of glucose homeostasis or hepatic glucose metabolism in an additional group of calorie-restricted diabetic rats, which was weight-matched with the selenate group. In addition, no obvious toxic side-effects on the kidney or liver were observed in the rats receiving selenate. In conclusion, selenate induces a sustained improvement of glucose homeostasis in streptozotocin-diabetic rats by an insulin-like action, which involves partial correction of altered pretranslational regulatory mechanisms in liver metabolism. [Diabetologia (1996) 39: 3-11]

Key words Selenium, glycolytic enzymes, gluconeogenic enzymes, gene expression, streptozotocin-diabetic rats.
Received: 19 April 1995

Corresponding author: Dr. J.-C.Henquin, Unité d'Endocrinologie et Métabolisme, UCL 5530, Avenue Hippocrate, 55, B-1200 Brussels, Belgium

Abbreviations: GK, Glucokinase; L-PK, L-type pyruvate kinase; PEP, phosphoenolpyruvate; PEPCK, phosphoenolpyruvate carboxykinase; $C$, non-diabetic control rats; $D$, untreated diabetic rats; WM, weight-matched diabetic rats; Se, selenatetreated diabetic rats; OGTT, oral glucose tolerance test; IVGTT, intravenous glucose tolerance test; STZ, streptozotocin; SSC, sodium saline citrate; SSPE, sodium saline phosphate ethylenediamine tetraacetic acid; GLUT2, glucose transporter isoform 2 .
Selenium is a ubiquitous trace element in nature [1] which has proved to be essential for humans [2]. Its deficiency produces an endemic fatal cardiomyopathy in Keshan, China [3] and a muscular dystrophy in patients submitted to long-term unsupplemented parenteral nutrition [4]. Its best-known biochemical role is as a component of the anti-oxidant enzyme glutathione peroxidase [5]. More recently, evidence has also been presented that selenium could affect carbohydrate metabolism.

Addition of sodium selenate to the incubation medium of adipocytes from normal rats stimulated glucose transport, cAMP phosphodiesterase activity 
and ribosomal $\mathrm{S}_{6}$ protein phosphorylation [6]. These in vitro insulin-like effects are in keeping with the observation that insulin-stimulated glucose oxidation was decreased in adipocytes from selenium-deficient rats [7]. Reports regarding the effects of selenium supplementation on plasma glucose levels in normal rats are conflicting: no change or a rise, especially at high doses, has been observed [8]. McNeill et al. [9] recently reported that frequent i.p. administration of selenate to streptozotocin (STZ)-diabetic rats for 7 weeks caused a sustained decrease in their hyperglycaemia. In this preliminary study, however, the animals were studied only under basal conditions, the conclusion that the effects of selenium were insulin-independent was based on a single measurement of plasma insulin, and the tissues involved in the hypoglycaemic action of selenium were not identified. Finally, whether or not the oral route is as efficient as the i.p. route for anti-diabetic purposes remains unknown.

Therefore, in the present work we evaluated the effects of an oral (rather than i.p.) administration of selenate for 10 weeks in STZ-diabetic rats. We characterized their glucose homeostasis in some detail, and determined whether the action of selenate was associated with a correction of the expression of genes involved in key steps of hepatic glucose metabolism and production. Thus, we measured mRNA levels (and activities) of glycolytic [glucokinase, (GK) and L-type pyruvate kinase (L-PK)] and gluconeogenic phosphoenolpyruvate carboxykinase (PEPCK) enzymes, and of the main glucose transporter isoform (GLUT2) in the livers of selenate-treated rats.

\section{Materials and methods}

Animals and experimental design. Two distinct series of 19 and 30 male Wistar/CPB rats (aged 7 weeks; weight $220 \pm 1 \mathrm{~g}$ ) purchased from IFFA Credo (Brussels, Belgium) were used. The animals were housed in individual cages at a constant temperature $\left(22^{\circ} \mathrm{C}\right)$ with a fixed 12 -h light-dark cycle (lights on from 07.00 to 19.00 hours). During week 7 of the experiment, they were housed in metabolic cages permitting measurement of daily fluid intake, and daily recording of food consumption and urine volume. All rats received ad libitum a standard laboratory chow in powdered form (A04; UAR, Villemoisson-surOrge, France) composed of (\% of wet weight): 59 carbohydrate, 3 fat, 17 protein, 21 water-minerals-cellulose.

The animals were divided into three (first series) or four (second series) experimental groups: non-diabetic control rats (C, $n=11 ; 5$ and 6 in series I and II, respectively); untreated diabetic rats $(\mathrm{D}, n=13 ; 6$ and 7 , respectively); diabetic rats treated with selenate ( $\mathrm{Se}, n=17 ; 8$ and 9 , respectively); diabetic rats submitted to calorie restriction to match their body weight with that of the selenate group (WM (weight-matched); $n=8$, series II only). Non-ketotic diabetes was induced by an i. v. injection of STZ (39 mg/kg body weight) into a tail vein. STZ (Upjohn Co, Kalamazoo, Mich., USA) was dissolved in cold $0.1 \mathrm{~mol} / \mathrm{l}$ citrate buffer ( $\mathrm{pH} 4.5$ ) immediately before use. Control animals received the buffer only. Five days after buffer in- jection, body weight, plasma glucose and insulin levels of control rats averaged $245 \pm 5 \mathrm{~g}, 6.6 \pm 0.2 \mathrm{mmol} / 1$ and $2.5 \pm 0.3 \mathrm{ng} /$ $\mathrm{ml}$, respectively. Five days after STZ injection, the diabetic rats were assigned to untreated, weight-matched or selenatetreated groups. The three groups of diabetic rats had similar initial body weight values (D, $228 \pm 3 \mathrm{~g}$; WM, $224 \pm 4 \mathrm{~g}$; Se, $227 \pm 2 \mathrm{~g}$ ) and fed plasma glucose levels (D, $23 \pm 1 \mathrm{mmol} / \mathrm{l}$; $\mathrm{WM}, 25 \pm 1 \mathrm{mmol} / 1$; Se, $23 \pm 1 \mathrm{mmol} / \mathrm{l})$. They also had, as seen a posteriori, similar initial fed plasma insulin concentrations (D, $1.2 \pm 0.2 \mathrm{ng} / \mathrm{ml}$; WM, $1.0 \pm 0.1 \mathrm{ng} / \mathrm{ml}$; Se, $1.2 \pm 0.1 \mathrm{ng} / \mathrm{ml}$ ). The treated group received increasing amounts of sodium selenate ( $\mathrm{Na}_{2} \mathrm{SeO}_{4}$; Aldrich Chem., Milwaukee, Wis., USA) in drinking solutions (distilled water empirically supplemented with $85 \mathrm{mmol} / 1$ or slightly flavoured with cocoa) and in food. The final concentration of sodium selenate (series $1,22 \mathrm{mg} / \mathrm{lin}$ water; series II, $14 \mathrm{mg} / \mathrm{l}$ in water and $20 \mathrm{mg} / \mathrm{kg}$ in food) was reached after 26 days of treatment and was maintained until the end of the study (10 weeks). This progressive increase permitted us to partially overcome the rats' aversion to selenate. However, a slight decrease in body weight was observed in Se rats during the treatment. In order to detect a possible influence of this slowing of body weight on glucose homeostasis, the third group of diabetic rats (WM) was submitted to mild calorie-restriction to ensure a body weight gain similar to that of Se rats. The amount of food given to WM rats was empirically adjusted daily and administered in two rations (one-third at 09.30 hours and two-thirds at 18.00 hours).

Blood sampling and tests. On several occasions, tail vein blood was collected from fed animals (between 08.30 and 09.00 hours) for determination of plasma glucose and insulin levels. All rats underwent an oral glucose tolerance test (OGTT) after 4 weeks of treatment. An intravenous glucose tolerance test (IVGTT) was also performed after 7 weeks in series I. On the day before the test, food was removed at 18.00 hours (thus, WM rats did not receive their evening ration). The tests started at 08.30 hours. For the OGTT, glucose (30\% in water) was introduced directly into the stomach through a fine gastric catheter at a dose of $2 \mathrm{~g} / \mathrm{kg}$ body weight. For the IVGTT, glucose was injected at a dose of $1 \mathrm{~g} / \mathrm{kg}$ body weight. Rats were gently wrapped in a towel to restrain them during injections or blood sampling.

After 10 weeks of treatment, the rats were killed by decapitation between 02.00 and 04.00 hours, i.e. in the absorptive state when the largest differences in mRNA levels and activities of glycolytic and gluconeogenic enzymes can be observed between normal and diabetic rats. The liver was immediately removed, frozen in liquid nitrogen and stored at $-70^{\circ} \mathrm{C}$ for subsequent RNA extraction and enzyme measurement. Larger samples of plasma were also saved.

RNA extraction and Northern blot analysis. This was performed on livers from series I rats only. Total RNA was isolated with an acid guanidinium-thiocyanate-phenol-chloroform mixture [10], after glycogen extraction [11]. The concentration of RNA was determined by absorbance at $260 \mathrm{~nm}$. All samples had a $260 / 280$ absorbance ratio of about 1.8. For Northern blot analysis, RNA $(30 \mu \mathrm{g})$ was denatured in a solution containing $2.2 \mathrm{mmol} / 1$ formaldehyde and $50 \%$ formamide $(\mathrm{v} / \mathrm{v})$ by heating at $95^{\circ} \mathrm{C}$ for $2 \mathrm{~min}$. RNA was then size-fractionated by $1 \%$ agarose gel electrophoresis, transferred to a Hybond-N membrane (Amersham Int., Amersham, Bucks., UK) and cross-linked by ultraviolet irradiation. The integrity and relative amounts of RNA were assessed by methylene blue staining of the blot.

The cDNA probes were kindly supplied by Drs. P. Iynedjian for GK [12], A. Kahn for L-PK [13], R. W. Hanson for PEPCK [14], and B.Thorens for GLUT2 [15]. Probes were labelled 
with ${ }^{32} \mathrm{P}$ using the Multiprime labelling system kit (Amersham). Hybridizations with L-PK, PEPCK or GLUT2 probes were carried out in a medium containing $42 \%$ deionized formamide, $40 \mathrm{mmol}-\mathrm{Tris} / \mathrm{HCl}(\mathrm{pH} 7.5), 8 \times$ Denhardt's solution (Denhardt $1 \times: 0.2 \mathrm{~g} / 1$ polyvinylpyrrolidone, $0.2 \mathrm{~g} / 1$ bovine serum albumin, $0.2 \mathrm{~g} / \mathrm{l}$ ficoll 400 ), $7.5 \%$ dextran sulphate, $0.1 \%$ sodium pyrophosphate, $1 \%$ SDS and denatured herring sperm DNA $(0.3 \mathrm{mg} / \mathrm{ml})$ at $42^{\circ} \mathrm{C}$ overnight. Hybridizations with GK probe were performed in $3 \times$ SSPE buffer (sodium saline phosphate ethylenediamine tetraacetic acid $1 \times, \mathrm{pH}$ 7.4: $8.77 \mathrm{~g} / 1 \mathrm{NaCl}, 1.38 \mathrm{~g} / 1 \mathrm{NaH}_{2} \mathrm{PO}_{4} . \mathrm{H}_{2} \mathrm{O}, 0.37 \mathrm{~g} / \mathrm{l}$ EDTA), $1 \%$ SDS, $1 \%$ glycine, $0.2 \%$ ficoll, $0.2 \%$ polyvinylpyrrolidone, $10 \%$ polyethylene glycol and denatured herring sperm DNA $(0.2 \mathrm{mg} / \mathrm{ml})$ at $65^{\circ} \mathrm{C}$ overnight. The membranes were washed twice for 30-60 $\mathrm{min}$ in $2 \times$ sodium saline citrate (SSC) $/ 0.1 \%$ SDS at $42^{\circ} \mathrm{C}$, and once for $15-30 \mathrm{~min}$ in $0.2-0.5 \times \mathrm{SSC} / 0.1 \%$ SDS at $65^{\circ} \mathrm{C}$ (L-PK) or $55^{\circ} \mathrm{C}$ (PEPCK, GLUT2). The membranes hybridized with GK were washed twice for $20 \mathrm{~min}$ in $2 \times \mathrm{SSPE} / 1 \% \mathrm{SDS}$ and once for $15 \mathrm{~min}$ in $0.5 \times \mathrm{SSPE} / 1 \%$ SDS at $65^{\circ} \mathrm{C}$. The filters were thereafter exposed to Kodak XOMAT AR films (Rochester, New York, USA), for 3-18 h at $-70^{\circ} \mathrm{C}$ with intensifying screens. Intensity of the mRNA bands on the blots was quantified by scanning densitometry (Ultroscan XL, LKB, Bromma, Sweden). To normalize the amount of total RNA loaded on each lane, specific mRNA levels were expressed relative to those of $\beta$-actin mRNA, a housekeeping gene which did not significantly vary between the three test groups. The levels of $\beta$-actin mRNA (in optical density units) averaged $2.17 \pm 0.38$ in $C$ rats, $2.56 \pm 0.39$ in D rats and $1.91 \pm 0.11$ in Se rats (mean \pm SEM for 5-8 rats; $p>0.05$ ).

Measurements of enzyme activities. These were performed in both series of rats at $37^{\circ} \mathrm{C}$. GK (EC 2.7.1.1) activity was determined using a spectrophotometric assay [16], by subtracting the hexokinase activity measured at $0.5 \mathrm{mmol} / \mathrm{l}$ glucose from the activity measured at $100 \mathrm{mmol} / \mathrm{l}$ glucose. Results were expressed as $\mu \mathrm{mol}$ NADPH produced $\cdot \mathrm{min}^{-1} \cdot \mathrm{g}$ liver $^{-1}$. L-PK (EC 2.7.1.40) was measured according to Blair et al. [17], at a subsaturating concentration of $1.3 \mathrm{mmol} / \mathrm{l}$ phosphoenolpyruvate (PEP) (active form of the enzyme) and at a saturating concentration of $6.6 \mathrm{mmol} / \mathrm{l} \mathrm{PEP} \mathrm{(maximal} \mathrm{activity} \mathrm{of} \mathrm{the} \mathrm{en-}$ zyme). Results were expressed as $\mu \mathrm{mol}$ NADH oxidized $\cdot \min ^{-1} \cdot \mathrm{g}$ liver ${ }^{-1}$. PEPCK (EC 4.1.1.32) activity was determined in liver cytosolic fractions using the $\mathrm{NaH}\left[{ }^{14} \mathrm{ClO}_{3}\right.$ fixation assay of Chang and Lane [18]. Results were expressed as $\mu \mathrm{mol} \mathrm{NaH}\left[{ }^{14} \mathrm{C}\right] \mathrm{O}_{3}$ fixed $\cdot \mathrm{min}^{-1} \cdot \mathrm{g}$ liver ${ }^{-1}$. One unit of enzyme is defined as the amount which catalyses the conversion of $1 \mu \mathrm{mol}$ substrate/min under the conditions mentioned above.

Analytical procedures. Plasma glucose was measured by a glucose oxidase method (Glucose Analyzer; Beckman, Fullerton, Calif., USA). Plasma insulin was determined by a double-antibody radioimmunoassay, using rat insulin as standard (Novo Research Institute, Bagsvaerd, Denmark). Pancreatic insulin was extracted by homogenization and sonication of the tissue in acidified ethanol. Plasma urea creatinine, glutamic-oxaloacetic transaminase, and glutamic-pyruvic transaminase were measured with a Hitachi 717 Automatic Analyzer (Tokyo, Japan). Proteinuria was determined by the method of Bradford (Bio-Rad, Munich, Germany) [19], using bovine serum albumin as standard. Plasma selenium was measured by electrothermal atomic absorption [20] with a Perkin Elmer apparatus (Model 3030; Uberlingen, Germany, with Zeeman corrector). Liver and urine samples were mineralized [21] and their selenium content was determined by spectrofluorimetry [22].
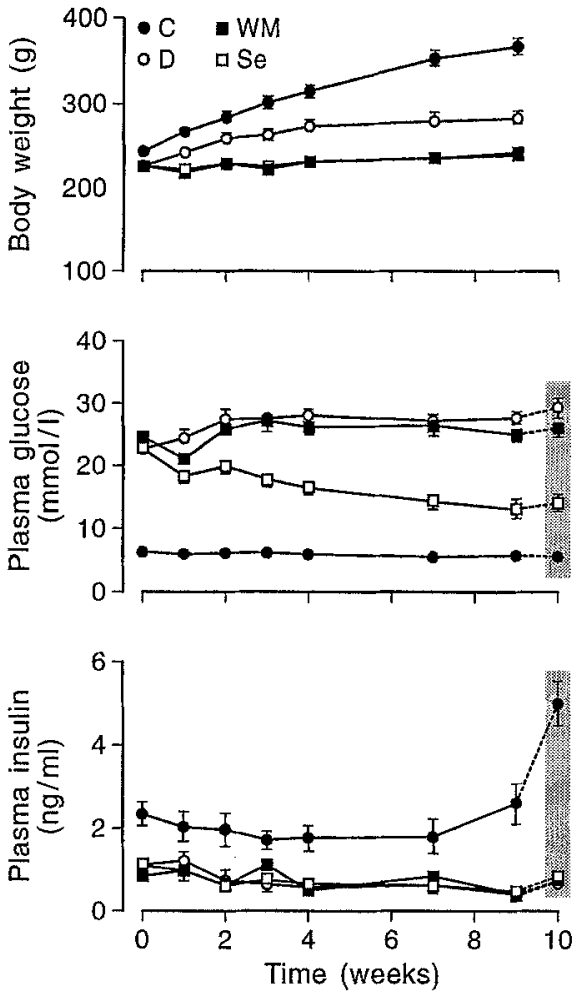

Fig. 1. Time course of the effects of selenate treatment on body weight, plasma glucose, and plasma insulin in diabetic rats. Control (C) rats were injected with citrate buffer and did not receive selenate. Diabetes was induced by streptozotocin: one group of diabetic rats was untreated (D), another group received $\mathrm{Na}_{2} \mathrm{SeO}_{4}$ in drinking solutions and food (Se), and a fourth was calorie-restricted to ensure a body weight gain similar to that of Se rats (weight-matched: WM). All measurements were made between 08.30-09.00 hours except those in the stippled area (02.00-04.00 hours). Values are mean \pm SEM for $11,13,8$ and 17 rats

\section{Statistical analysis}

Results are given as the mean \pm SEM for the indicated number of rats. Comparisons between control, diabetic, weight-matched and selenate-treated diabetic rats were carried out by analysis of variance followed by the Newman-Keuls test for multiple comparisons [23]. Differences were considered statistically significant at $p$ less than 0.05 .

\section{Results}

The untreated diabetic (D) rats gained weight at a much lower rate than the control (C) rats (Fig.1). Compared to $\mathrm{D}$ rats, the body weight of the selenate-treated diabetic $(\mathrm{Se})$ rats was slightly decreased because of some aversion to the element. The body weight of the weight-matched diabetic (WM) rats was consistently similar to that of Se rats (Fig. 1).

Average fed plasma glucose levels (at 09.00 hours) were around $25 \mathrm{mmol} / \mathrm{l}$ in D rats. Hyperglycaemia was only transiently decreased by calorie restriction in WM rats $(p<0.05$ vs $\mathrm{D}$ rats solely during week 1$)$. 

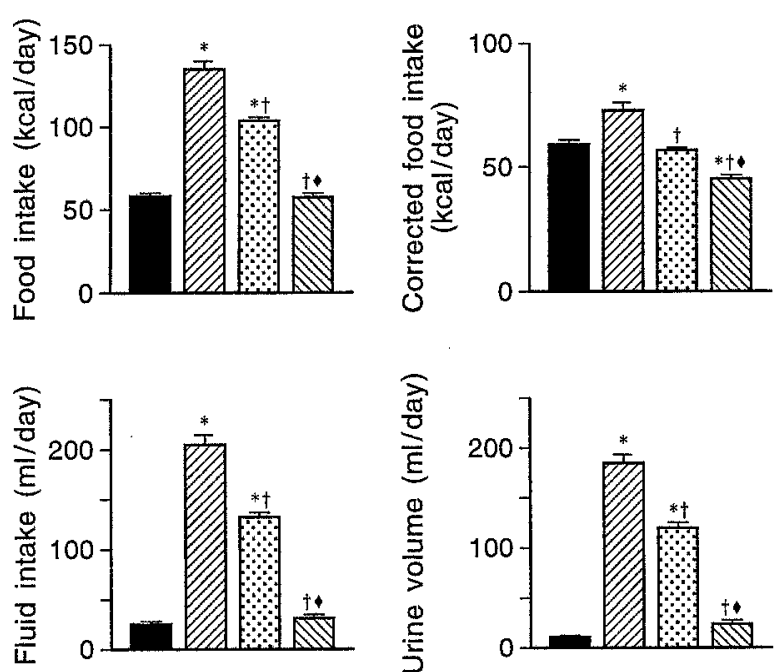
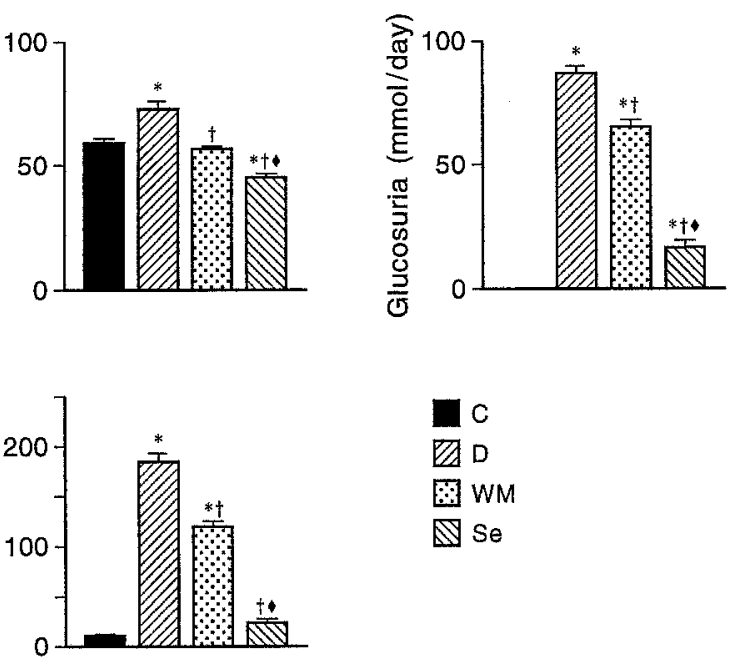

Fig. 2. Metabolic balance of control (C), untreated diabetic (D), weightmatched diabetic 器 (WM) and selenate-treated diabetic (Se) rats. Measurements were made daily during week 7 of the treatment, while the animals were housed in metabolic cages. Corrected food intake corresponds to total intake minus calories lost as glucose in urine. Values are mean \pm SEM for $11,13,8$ and 17 rats. $* p<0.001$ vs $C$ rats; $+p<0.001$ vs D rats; $p<0.001$ vs WM rats
In contrast, a sustained and pronounced decrease in plasma glucose levels was observed in Se rats ( $p<0.01$ or less vs WM rats from the second week onward). After 9 weeks, this fall amounted to $\sim 50 \%$ (Fig. 1).

Fed plasma insulin levels were similar in the three groups of diabetic rats and were markedly reduced compared to those of $\mathrm{C}$ rats $(p<0.05$ or less at each sampling). The difference was particularly striking when measurements were made during the night, when the animals were in an absorptive state $(02.00-$ 04.00 hours) (Fig. 1).

The metabolic balance of the four groups of rats was measured during week 7 of the treatment (Fig.2). Daily food intake was doubled in D rats. It proved necessary to only moderately reduce $(-23 \%)$ food consumption of WM rats to ensure a body weight evolution similar to that of Se rats. By contrast, selenium administration totally reversed the diabetic polyphagia. When food intake was corrected for urinary losses of glucose, energy consumption remained lower $(-23 \%)$ in Se than in $\mathrm{C}$ rats, suggesting that selenium itself exerts a mild anorexigenic effect. The important glucosuria of $\mathrm{D}$ rats was diminished by 25 and $80 \%$ in WM and Se rats, respectively. This may explain, at least in part, why urine volume and fluid intake were modestly reduced in WM rats and completely corrected by selenate treatment.

After an overnight fast, plasma glucose concentrations in Se rats $(5.4 \pm 0.1 \mathrm{mmol} / 1$; mean values obtained at time zero of the OGTT) were lower ( $p<0.05$ or less) than in $\mathrm{D}$ rats $(6.6 \pm 0.1 \mathrm{mmol} / \mathrm{l})$ or WM rats $(8.4 \pm 0.9 \mathrm{mmol} / \mathrm{l})$, but were not different from those in $\mathrm{C}$ rats $(4.5 \pm 0.1 \mathrm{mmol} / \mathrm{l})$. Fasting plasma insulin levels were similar in the four groups of rats (in $\mathrm{ng} / \mathrm{ml}$ : C, $0.43 \pm 0.03 ; \mathrm{D}, 0.53 \pm 0.05$; WM, $0.50 \pm 0.09 ; \mathrm{Se}, 0.40 \pm 0.04)$.

During the OGTT, plasma glucose levels of $\mathrm{C}$ rats remained below $10 \mathrm{mmol} / \mathrm{l}$ (Fig. 3), but rose to
$30 \mathrm{mmol} / \mathrm{l}$ and did not return to basal values at the end of the test in D rats. They were even slightly higher ( $p<0.05$ vs D rats from 60 min onward) in WM rats. By contrast, plasma glucose concentrations in Se rats were consistently lower ( $p<0.01$ or less) than those in D or WM rats, and decreased to control values at $180 \mathrm{~min}$. The integrated glucose response (area under the curve and above basal levels) was approximately $50 \%$ lower in Se than in D and WM rats $(p<0.001)$, but remained threefold higher than in $\mathrm{C}$ rats. A marked rise in plasma insulin levels was observed in $\mathrm{C}$ rats, which contrasted with the almost complete absence of change in the three groups of diabetic animals. The integrated insulin responses were not different in Se, WM and D rats and were $80 \%$ lower than those in $\mathrm{C}$ rats.

During the IVGTT (series I only) (Fig.4), glucose concentrations in Se rats were lower than in $\mathrm{D}$ rats from 15 min onward $(p<0.01)$ and returned to control levels at $120 \mathrm{~min}$. The glucose disappearance rate $\left(\mathrm{K}_{\mathrm{G}}\right.$, slope of the logarithm of glucose levels between 5 and $60 \mathrm{~min})$ was twofold higher $(p<0.01)$ in Se rats $(1.37 \pm 0.17 \% / \mathrm{min})$ than in $\mathrm{D}$ rats $(0.64 \pm 0.05 \% / \mathrm{min})$, but remained lower than in $\mathrm{C}$ rats $(2.27 \pm 0.18 \% / \mathrm{min})$. The integrated glucose response in Se rats was similar to that in $\mathrm{C}$ rats and was reduced by about $40 \%$ compared with that in $D$ rats. A strong rise in plasma insulin levels was again observed in $\mathrm{C}$ rats only. Thus, the integrated insulin responses of treated and untreated STZ rats remained blunted compared with those of normal rats.

Pancreatic insulin reserves (in $\mu \mathrm{g} /$ pancreas) were reduced by more than $90 \%(p<0.001)$ in $\mathrm{Se}$ $(17 \pm 3)$, WM $(6 \pm 1)$, and D rats $(6 \pm 1)$ compared with those in $C$ rats $(208 \pm 13)$.

Hepatic glycogen stores measured in series I only (in $\mathrm{mg} / \mathrm{g}$ ), were decreased threefold in $\mathrm{D}$ rats compared with $C$ rats $(11.5 \pm 0.9$ vs $33.9 \pm 3.5 ; p<0.01)$ and were not replenished by selenium administration $(16.1 \pm 2.1)$. In contrast, selenate treatment par- 

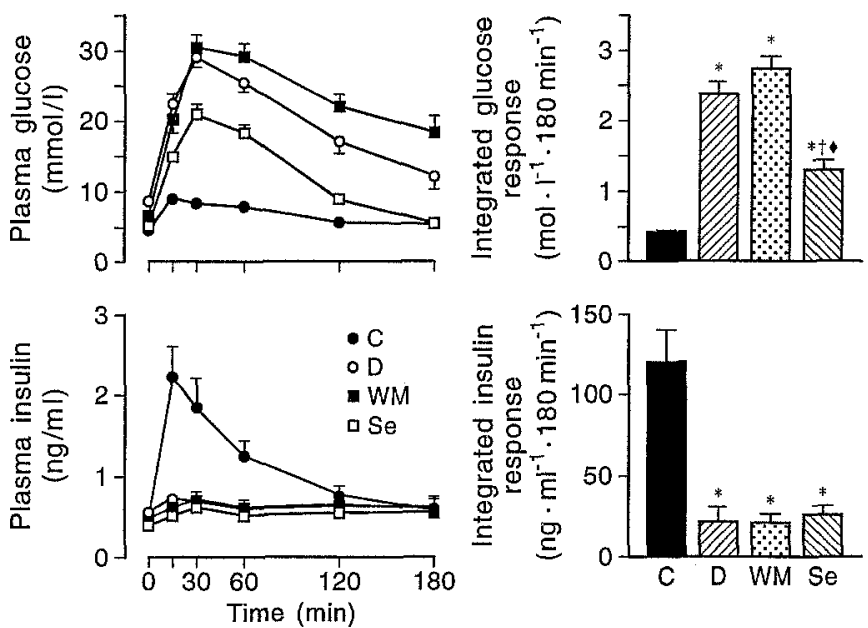

Fig. 3. Left panels, Plasma glucose and insulin levels during an oral glucose tolerance test (OGTT) in control (C), untreated diabetic (D), weight-matched diabetic (WM) and selenatetreated diabetic (Se) rats. Right panels, Integrated glucose and insulin responses during the OGTT. The test was performed after 4 weeks of treatment. Values are mean \pm SEM for $11,13,8$ and 17 rats. ${ }^{*} p<0.001$ vs $\mathrm{C}$ rats; $+p<0.001$ vs $\mathrm{D}$ rats; $p<0.001$ vs WM rats
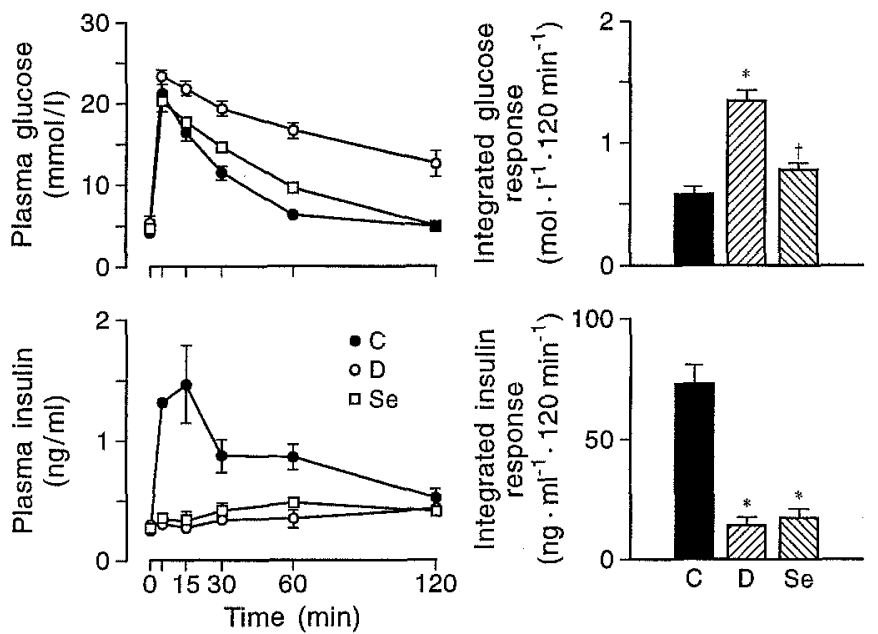

Fig. 4. Left panels, Plasma glucose and insulin levels during an intravenous glucose tolerance test (IVGTT) in control (C), untreated diabetic (D), and selenate-treated diabetic (Se) rats (series I). Right panels, Integrated glucose and insulin response during the IVGTT. The test was performed after 7 weeks of treatment. Values are mean \pm SEM for five, six and eight rats. ${ }^{*} p<0.01$ vs C rats; $+p<0.01$ vs $\mathrm{D}$ rats

tially corrected activity and expression of glycolytic and gluconeogenic enzymes in livers of diabetic rats (series I and II). The activities of two major glycolytic enzymes, GK and L-PK, were decreased by $\sim 90$ and $\sim 70 \%$, respectively in diabetic animals (Table 1). They remained unchanged by mere caloric restriction, but were increased $\sim$ two- to threefold by selenate treatment to reach $\sim 50-74 \%$ of the values in C rats. A 4.5-fold rise in the activity of the key gluconeogenic enzyme, PEPCK, was induced by diabe- tes. This again remained unchanged in WM rats, but was corrected by selenate administration (Table 1 ).

We next examined whether selenate-related changes in enzyme activities were associated with changes in corresponding mRNA levels. This was performed in rats from series I. Yields of total hepatic RNA did not differ between the experimental groups (C, $4.8 \pm 0.2 \mathrm{mg} / \mathrm{g} ; \mathrm{D}, \quad 5.1 \pm 0.3 \mathrm{mg} / \mathrm{g}$; Se, $4.4 \pm 0.2 \mathrm{mg} / \mathrm{g})$. The abundance of specific mRNAs was assessed by Northern blot analysis. GK mRNA (2.4 kilobases) and L-PK mRNA (2, 2.2 and 3.2 kilobases) transcripts were barely detectable in livers of D rats, whereas some restoration was observed after selenate treatment (Fig.5). In good agreement with changes in enzyme activities, quantification of autoradiographic signals showed that GK and L-PK mRNAs, which were decreased by 90 and $80 \%$, respectively in diabetic livers, were partially restored by selenate treatment (to $-40-60 \%$ of $\mathrm{C}$ values) (Fig. 6). On the other hand, the strong rise (11fold) in PEPCK mRNA produced by diabetes was reduced by $\sim 40 \%$ in Se rats (Figs. 5,6 ).

In keeping with previous reports [24-27], a twofold augmentation of GLUT2 mRNA was found in livers of STZ-rats (Figs. 5, 6). This is thought to contribute to the increased glucose output from diabetic liver [24]. However, transport is not limiting for hepatic glucose metabolism or export [28]. Selenate treatment did not modify liver GLUT2 mRNA (Figs. 5, 6).

Daily consumption of sodium selenate averaged $3.09 \pm 0.32 \mathrm{mg} / \mathrm{kg}$ body weight per day in treated rats $(n=17)$, which corresponds to $1.29 \pm 0.14 \mathrm{mg}$ selenium element $/ \mathrm{kg}$ body weight per day. Concentrations of selenium were increased by $64 \%$ in plasma and sixfold in liver of treated rats compared with untreated (C and D) animals. Urinary excretion of selenium was also increased in Se rats (Table 2).

As shown in Table 3, selenate treatment had no obvious toxic side-effects on kidney or liver. The creatinine clearance which was increased in $\mathrm{D}$ rats, due to the glomerular hyperfiltration rate [29], was normalized in Se rats. Daily proteinuria was also corrected. The rise in plasma urea observed in both groups of STZ rats may reflect a marginal dehydration, due to either increased urinary volume ( $D$ rats) or decreased fluid consumption (Se rats). Liver cytolytic enzymes were not increased, but actually even decreased (glutamic-pyruvic transaminase) after selenate treatment (Table 3 ).

\section{Discussion}

The present study confirms that selenate treatment lowers plasma glucose concentrations in STZ-diabetic rats [9]. It further demonstrates that oral administration of selenium is effective and that the hypo- 
Table 1. Effects of selenate treatment on GK, L-PK and PEPCK activities in the livers of diabetic rats

\begin{tabular}{lllll}
\hline & U/g liver & & \\
\cline { 2 - 5 } & Control & Untreated diabetic & Weight matched diabetic & Selenate treated \\
\hline$n$ & 11 & 13 & 8 & 17 \\
GK & $1.31 \pm 0.17$ & $0.18 \pm 0.02^{\mathrm{a}}$ & $0.16 \pm 0.04^{\mathrm{a}}$ & $0.62 \pm 0.10^{\mathrm{a}, \mathrm{b}, \mathrm{c}}$ \\
L-PK & & & & \\
PEP $1.3 \mathrm{mmol} / 1$ & $33.7 \pm 3.7$ & $10.7 \pm 1.9^{\mathrm{a}}$ & $13.7 \pm 2.0^{\mathrm{a}}$ & $25.0 \pm 1.7^{\mathrm{a}, \mathrm{b}, \mathrm{c}}$ \\
PEP 6.6 mmol/1 & $97.8 \pm 10.9$ & $21.5 \pm 2.9^{\mathrm{a}}$ & $26.3 \pm 5.5^{\mathrm{a}}$ & $62.0 \pm 4.1^{\mathrm{a}, \mathrm{b}, \mathrm{c}}$ \\
PEPCK & $0.71 \pm 0.06$ & $3.19 \pm 0.37^{\mathrm{a}}$ & $3.02 \pm 0.30^{\mathrm{a}}$ & $1.15 \pm 0.12^{\mathrm{b}, \mathrm{c}}$ \\
\hline
\end{tabular}

Values are mean \pm SEM. Measurements made after 10 weeks of treatment. L-PK was measured at $1.3 \mathrm{mmol} / \mathrm{l} \mathrm{PEP}$ (active form of the enzyme) and at $6.6 \mathrm{mmol} / 1 \mathrm{PEP}$ (maximal activity

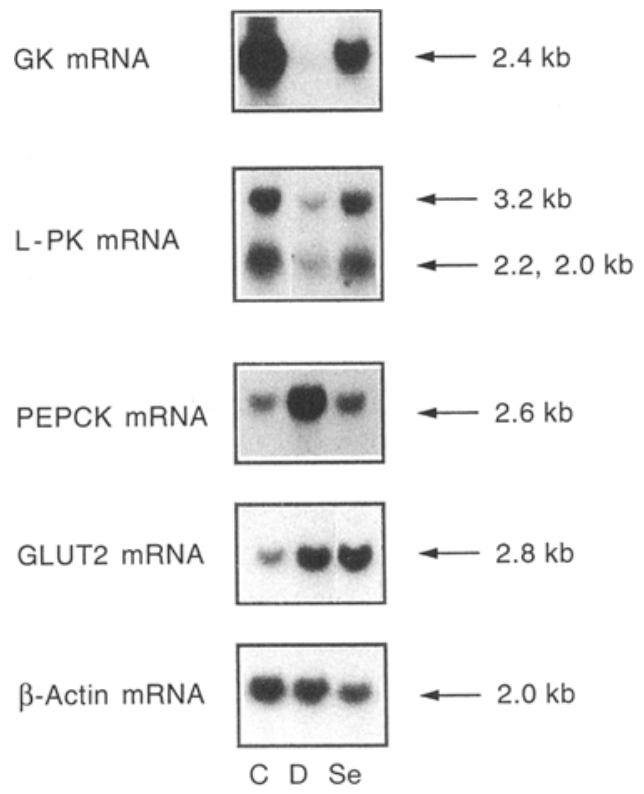

Fig.5. Northern blot analysis of glucokinase (GK), L-type pyruvate kinase (L-PK), phosphoenolpyruvate carboxykinase (PEPCK) and GLUT2 transporter mRNA in liver from control (C), untreated diabetic (D) and selenate-treated diabetic (Se) rats. All lanes were loaded with $30 \mu \mathrm{g}$ of total RNA. The filters were then successively hybridized with the different radiolabelled cDNA probes. Representative of five-eight different rats in each group. kb, Kilobase

glycaemic action of the element can be observed during glucose tolerance tests as well as under basal conditions, and is clearly independent from a rise in circulating insulin levels or decrease in food intake and slowing of body weight gain. It also shows that the blood glucose-lowering effect of selenate results in part from restoration of glucose metabolism in the diabetic liver.

In our study, i.p. selenate gave less consistent results than the oral route (D. J. Becker and B. Reul, unpublished data). Some heterogeneity in the hypoglycaemic responses has also been reported by McNeill et al. after i,p. treatment [9]. Moreover, it should be noted that acute i.p. selenium administered to normal rats may induce hyperglycaemia, at of the enzyme). ${ }^{a} p<0.01$ or less vs C rats; ${ }^{b} p<0.01$ or less vs $\mathrm{D}$ rats; ${ }^{\mathrm{c}} p<0.05$ or less vs $\mathrm{WM}$ rats

least when relatively high doses of sodium selemite $(1.6 \mathrm{mg} / \mathrm{kg}$ or more $)$ are used [8].

A moderate decrease in body weight, which is likely to be due to a reduction in food intake, was observed in Se rats compared with D rats. This is reminiscent of the anorexigenic effect reported in diabetic rats treated with vanadate, a well-established insulin-like agent [30]. It has recently been claimed that the antihyperglycaemic action of vanadate was entirely attributable to its inhibition of feeding and slowing of body weight gain [31]. This made it important to compare Se rats, not only with diabetic rats fed ad libitum (D), but also with calorie-restricted and body-weight matched STZ (WM) rats, to distinguish between genuine effects of the element and effects secondary to reduction of body weight. Our results clearly show that the lowering of blood glucose and the improvement of hepatic glucose metabolism brought about by selenium cannot be ascribed to the decrease in food intake.

Several other mechanisms could theoretically contribute to the blood glucose-lowering action of oral selenate in chronically treated diabetic rats. First, an inhibition of intestinal glucose transport by selenate has been observed in vitro [32]. However, this only occurred at a concentration of selenate $(1 \mathrm{mmol} / \mathrm{l})$, one order of magnitude higher than that actually reached in the drinking solutions given to the rats $(\sim 0.1 \mathrm{mmol} / \mathrm{l})$. Moreover, the influence of selenate was detectable during IVGTT as well as OGTT, and in fasted animals. Second, an acceleration of renal glucose excretion can also be excluded since glucosuria was decreased in Se rats. In this respect, the hypoglycaemic action of selenate entirely differs from that of phlorizin [33]. Third, a decrease in insulin counterregulatory hormones could contribute; however, acute selenium treatment has actually been shown to increase plasma corticosterone levels in normal rats [8]. Fourth, an insulin-like action on the insulin target tissues is likely to be of major importance in the in vivo effects of selenate [9]. This is supported by the significant improvement in tolerance to oral or i.v. glucose despite the lack of changes in circulating insulin levels and pancreatic insulin stores. 

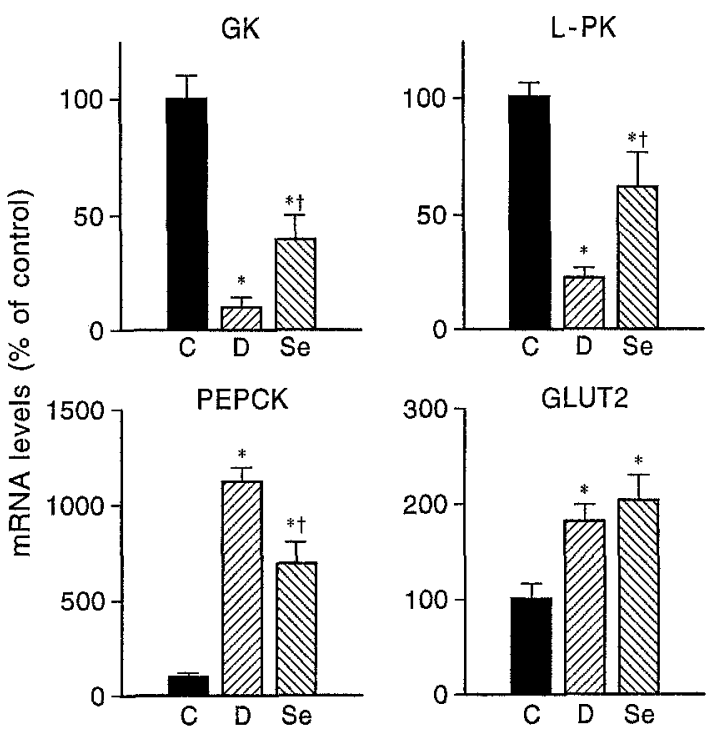

Fig. 6. Effects of selenate treatment on glucokinase (GK), Ltype pyruvate kinase (L-PK), phosphoenolpyruvate carboxykinase (PEPCK) and GLUT2 transporter mRNA in liver of diabetic rats. Values are means \pm SEM for five, six and eight control (C), untreated diabetic (D) and selenate-treated diabetic (Se) rats (series I). mRNA levels were quantified by scanning densitometry of autoradiographic signals obtained from Northern blots. Results are expressed as percentages of values in $\mathrm{C}$ rats. $* p<0.05$ or less vs $\mathrm{C}$ rats; $+p<0.05$ or less vs $\mathrm{D}$ rats

This is also evidenced by the effects in the liver where selenate treatment partially restored mRNA levels and activities of two key glycolytic enzymes (GK and L-PK). It also decreased the elevated mRNA concentration and activity of a major gluconeogenic enzyme (PEPCK). Thus, oral selenate partially shifted the predominating gluconeogenic flux, which prevails in the diabetic liver, into a glycolytic flux. Interestingly, the concentration of selenium in the liver of treated rats $(70 \mu \mathrm{mol} / \mathrm{kg})$ is close to that at which it elicits insulin-like effects in vitro $(100 \mu \mathrm{mol} / 1)$ [6]. Some of the in vivo effects of selenium may be reproduced by treatment with phlorizin and might therefore partly be due to an alleviation of glucose toxicity in the liver [27]. However, phlorizin treatment modified neither the activity (at both PEP concentrations) nor mRNA levels of L-PK, suggesting that other mechanisms (i.e. an insulin-like action) may play a determinant role in the in vivo effects of selenium on liver metabolism. Thus far, the in vitro insulin-like effects of selenium have only been studied in adipocytes [6]. It is clear that such an action on muscle and adipose tissue, which was not explored in this study, may also substantially contribute to the anti-diabetogenic effects of selenium treatment.

The effects of selenium on glucose homeostasis and liver metabolism in diabetic rats are similar to those of vanadium and several other trace elements $[26,30,34-38]$. This similarity raises the possibility that those elements could exert non-specific actions
Table 2. Changes in plasma and liver selenium concentrations and urinary selenium excretion induced by selenate treatment in diabetic rats

\begin{tabular}{lccc}
\hline Selenium & Control & $\begin{array}{l}\text { Untreated } \\
\text { diabetic }\end{array}$ & $\begin{array}{l}\text { Selenate } \\
\text { treated }\end{array}$ \\
\hline$n$ & 5 & 6 & 8 \\
Plasma $(\mu \mathrm{g} / \mathrm{dl})$ & $42 \pm 2$ & $46 \pm 2$ & $72 \pm 2^{\mathrm{a}, \mathrm{b}}$ \\
Liver $(\mu \mathrm{g} / \mathrm{g})$ & $0.80 \pm 0.06$ & $0.97 \pm 0.03$ & $5.62 \pm 0.61^{\mathrm{a}, \mathrm{b}}$ \\
Urine $(\mu \mathrm{g} / 24 \mathrm{~h})$ & $11 \pm 8$ & $5 \pm 0.3$ & $143 \pm 14^{\mathrm{a}, \mathrm{b}}$ \\
\hline
\end{tabular}

Values are mean \pm SEM. Plasma and liver selenium concentrations were measured after 10 weeks of treatment. Urinary excretion of selenium was determined while the animals were housed in metabolic cages (week 7). ${ }^{a} p<0.01$ vs control rats; ${ }^{\mathrm{b}} p<0.01$ vs untreated diabetic rats

Table 3. Effects of selenate treatment on renal function, proteinuria and on liver cytolytic enzymes in diabetic rats

\begin{tabular}{lccc}
\hline & Control & $\begin{array}{l}\text { Untreated } \\
\text { diabetic }\end{array}$ & $\begin{array}{l}\text { Selenate } \\
\text { treated }\end{array}$ \\
\hline$n$ & 5 & 6 & 8 \\
Plasma & & & \\
Urea (mmol/1) & $12.1 \pm 0.4$ & $17.9 \pm 1.1^{\mathrm{a}}$ & $21.4 \pm 1.4^{\mathrm{a}}$ \\
Creatinine (umol/1) & $36.2 \pm 1.8$ & $41.5 \pm 1.8$ & $30.9 \pm 0.9$ \\
GOT (IU/1) & $161 \pm 20$ & $162 \pm 63$ & $117 \pm 7$ \\
GPT (IU/1) & $50 \pm 4$ & $116 \pm 36^{\mathrm{b}}$ & $75 \pm 6$ \\
Creatinine clearance $(\mathrm{ml} / \mathrm{min})$ & $2.37 \pm 0.17$ & $3.47 \pm 0.36^{\mathrm{b}}$ & $2.21 \pm 0.16^{\mathrm{c}}$ \\
Proteinuria $(\mathrm{mg} / 24 \mathrm{~h})$ & $16 \pm 2$ & $43 \pm 7^{\mathrm{a}}$ & $17 \pm 5^{\mathrm{c}}$ \\
\hline
\end{tabular}

Values are mean \pm SEM. Measurements were made after 10 weeks of treatment, except those of urinary determinations (week 7 , during housing in metabolic cages). Two samples were taken for daily proteinuria and the obtained values were averaged for each rat. GOT, glutamic-oxaloacetic transaminase; GPT, glutamic-pyruvic transaminase. ${ }^{a} p<0.01$ vs control rats; ${ }^{\mathrm{b}} p<0.05$ vs control rats; ${ }^{\mathrm{c}} p<0.01$ vs untreated diabetic rats

on glucose metabolism. This is unlikely for several reasons. First, selenium and vanadium belong to distinct groups of elements in the periodic table, and exhibit quite different physico-chemical properties: selenium is primarily an anti-oxidant, vanadium an inhibitor of ATPases and phosphatases $[1,39,40]$. Second, in contrast to selenium, vanadium treatment totally replenished glycogen stores in diabetic liver [30, $36,41,42]$. This occurred even in rats given a low concentration of vanadate, in which glycaemia was only very modestly decreased [30]. Third, evidence has been presented that trace elements may specifically affect different pathways of glucose metabolism in diabetic rats. Thus, lithium and vanadium administered to partially pancreatectomized rats stimulated their muscle glycogen synthesis, while combined zinc and magnesium therapy specifically enhanced their whole-body glycolytic rate [38].

In conclusion, oral selenate induces a sustained improvement of glucose homeostasis in STZ-diabetic rats by an insulin-like action, which involves partial correction of altered pretranslational regulatory mechanisms in liver metabolism. Additional 
studies are necessary to establish whether small doses of selenium, which also possess interesting anti-oxidant properties, may be useful as an adjunctive therapy in human diabetes.

Acknowledgements. We thank Drs. P. Iynedjian (Geneva, Switzerland), A.Kahn (Paris, France), R.W.Hanson (Cleveland, Ohio, USA) and B. Thorens (Lausanne, Switzerland) for kindly providing us with the cDNA probes used in this study. We are grateful to Ms. A.-M. Pottier for skilful assistance and to Professor R.de Hertogh for ultracentrifuge facilities. This work was supported by grants (3. 4513. 93) from the Foundation of Scientific and Medical Research (Brussels) and by a grant from the Fund for Scientific Development (University of Louvain). D.J.B. holds a research fellowship from the Ministry of National Education of Luxemburg and S.M. B. is Chercheur Qualifié of the Fonds National de la Recherche Scientifique (Brussels).

\section{References}

1. Wilber CG (1980) Toxicology of selenium: a review. Clin Toxicol 17: 171-230

2. Lederer J (1986) Selenium et vitamine E. Maloine, Paris, pp 1-376

3. Yang G, Chen J, Wen Z, Ge K (1984) The role of selenium in Keshan disease. In: Drapper HH (ed) Advances in nutritional research. Plenum Press, New York, pp 203 231

4. Van Rij AM, Thomson CD, McKenzie JM, Robinson MF (1979) Selenium deficiency in total parenteral nutrition. Am J Clin Nutr 32: 2085-2086

5. Rotruck JT, Pope AL, Ganther HE, Swanson AB, Hafeman DG, Hoekstra WG (1973) Selenium: biochemical role as a component of the glutathione peroxidase. Science 179: $588-590$

6. Ezaki O (1990) The insulin-like effects of selenate in rat adipocytes. J Biol Chem 265: 1124-1128

7. Souness JE, Stouffer JE, Chagoya de Sanchez V (1983) The effects of selenium deficiency on rat fat cell glucose oxidation. Biochem J 214: 471-477

8. Rasekh HR, Potmis RA, Nonavinakere VK, Early JL, Iszard MD (1991) Effect of selenium on plasma glucose of rats: the role of insulin and glucocorticoids. Toxicol Lett 58: 199-207

9. McNeill JH, Delgatty HLM, Battel ML (1991) Insulin-like effects of sodium selenate in STZ-induced diabetic rats. Diabetes 40: 1675--1678

10. Chomczynski P, Sacchi N (1987) Single-step method of RNA isolation by acid guanidinium-thiocyanate-phenolchloroform extraction. Anal Biochem 162: 156-159

11. Sambrook J, Fritsch EF, Maniatis T (1989) Extraction, purification and analysis of messenger RNA from eukaryotic cells. In: Ford N, Nolan C, Fergusson M (eds) Molecular cloning. A laboratory manual Vol 1. Cold Spring Harbor Laboratory Press, New York, p 7.22

12. Iynedjian PB, Ucla C, Mach B (1987) Molecular cloning of glucokinase cDNA. Developmental and dietary regulation of glucokinase mRNA in rat liver. J Biol Chem 262: 60326038

13. Simon MP, Besmond C, Cottreau D et al. (1983) Molecular cloning for rat L-type pyruvate kinase and aldolase B. J Biol Chem 258: 14576-14584

14. Yoo-Warren H, Monahan JE, Short J et al. (1983) Isolation and characterization of the gene coding for cytosolic phos- phoenolpyruvate carboxykinase (GTP) from the rat. Proc Natl Acad Sci USA 80: 3656-3660

15. Thorens B, Sarkar HK, Kaback HR, Lodish HF (1988) Cloning and functional expression of a novel glucose transporter present in liver, intestine, kidney and $\beta$-pancreatic islet cells. Cell 55: 281-290

16. Newgard CB, Hirsch LJ, Foster DW, McGarry JD (1983) Studies on the mechanism by which exogenous glucose is converted into liver glycogen in the rat. J Biol Chem 258: 8046-8052

17. Blair JB, Cimbala MA, Foster JL, Morgan RA (1976) Hepatic pyruvate kinase. Regulation by glucagon, cyclic adenosine $3^{\prime}: 5^{\prime}$-monophosphate, and insulin in the perfused rat liver. J Biol Chem 251: 3756-3762

18. Chang HC, Lane MD (1966) The enzymatic carboxylation of phosphoenolpyruvate. II. Purification and properties of liver mitochondrial phosphoenolpyruvate carboxykinase. J Biol Chem 241: 2413-2420

19. Bradford M (1976) A rapid and sensitive method for the quantification of microgram quantities of protein utilizing the principle of protein-dye binding. Anal Biochem 72: 248-254

20. Alfthan G, Kumpulainen J (1982) Determination of selenium in small volumes of blood plasma and serum by electrothermal atomic absorption spectrometry. Anal Chim Acta 140: 221-227

21. Welz B, Melcher M, Nève J (1984) Determination of selenium in human body fluids by hybride-generation atomic absorption spectrometry. Optimization of sample composition. Anal Chim Acta 165: 131-140

22. Robberecht HJ, Deelstra HA (1984) Selenium in human urine. Determination, speciation and concentration levels. Talanta 31: 497--508

23. Sokal RR, Rohlf FJ (1969) Biometry. The principles and practice of statistics in biological research. Freeman, San Francisco, pp 1-776

24. Oka Y, Asano T, Shibasaki Y et al. (1990) Increased liver glucose-transporter protein and mRNA in STZ-induced diabetic rats. Diabetes 39: 441-446

25. Burcelin R, Kande J, Eddouks M, Assan R, Girard J (1992) Evidence that GLUT2 mRNA and protein concentrations are decreased by hyperinsulinemia and increased by hyperglycemia in liver of diabetic rats. Biochem $\mathrm{J} 288$ : 675-679

26. Brichard SM, Desbuquois B, Girard J (1993) Vanadate treatment of diabetic rats reverses the impaired expression of genes involved in hepatic glucose metabolism. Effects on glycolytic and gluconeogenic enzymes, and on glucose transporter GLUT2. Mol Cell Endocrinol 91: 91-97

27. Brichard SM, Henquin JC, Girard J (1993) Phlorizin treatment of diabetic rats partially reverses the abnormal expression of genes involved in hepatic glucose metabolism. Diabetologia 36: 292-298

28. Granner D, Pilkis S (1990) The genes of hepatic glucose metabolism. J Biol Chem 265: 10173-10176

29. Jensen PK, Christiansen JS, Steven K, Parving HH (1981) Renal function in streptozotocin-diabetic rats. Diabetologia 21: 409-414

30. Brichard SM, Okitolonda W, Henquin JC (1988) Long term improvement of glucose homeostasis by vanadate treatment in diabetic rats. Endocrinology 123: 20482053

31. Malabu UH, Dryden S, McCarthy HD, Kilpatrick A, Williams G (1994) Effects of chronic vanadate administration in the STZ-induced diabetic rat: the antihyperglycemic action of vanadate is entirely attributable to its suppression of feeding. Diabetes 43: 9-15 
32. Wolffram S, Arduser F, Scarrer E (1985) In vivo intestinal absorption of selenate and selenite by rats. J Nutr 115 : 454-459

33. Starke A, Grundy S, McGarry JD, Unger RH (1985) Correction of hyperglycemia with phlorizin restores the glucagon response to glucose in insulin-deficient dogs: implications for human diabetes. Proc Natl Acad Sci USA 82: 1544-1546

34. Heyliger CE, Tahiliani AG, McNeill JH (1985) Effect of vanadate on elevated blood glucose and depressed cardiac performance of diabetic rats. Science 227: 1474-1477

35. Meyerovitch J, Farfel Z, Sack J, Shechter Y (1987) Oral administration of vanadate normalizes blood glucose levels in streptozotocin-treated rats. J Biol Chem 262: 6658-6662

36. Gil J, Miralpeix M, Carreras J, Bartrons R (1988) Insulinlike effects of vanadate on glucokinase activity and fructose 2,6-bisphosphate levels in the liver of diabetic rats. J Biol Chem 263: 1868-1871

37. Valera A, Rodriguez-Gil JE, Bosch F (1993) Vanadate treatment restores the expression of genes for key en- zymes in the glucose and ketone bodies metabolism in the liver of diabetic rats. J Clin Invest 92; 4-11

38. Rossetti L, Giaccari A, Klein-Robbenhaar E, Vogel LR (1990) Insulinomimetic properties of trace elements and characterization of their in vivo mode of action. Diabetes 39: $1243-1250$

39. Swarup G, Speeg KV, Cohen S, Garbers DL (1982) Phosphotyrosyl-protein phosphatase of TCRC-2 cells. J Biol Chem 257: 7298-7301

40. Nechay BR (1984) Mechanisms of action of vanadium. Ann Rev Pharmacol Toxicol 24: 501-524

41. Bollen M, Miralpeix M, Ventura F, Toth B, Bartrons R, Stalmans W (1990) Oral administration of vanadate to streptozotocin-diabetic rats restores the glucose-induced activation of liver glycogen synthase. Biochem J 267: 269271

42. Pugazhenthi S, Khandelwal RL (1990) Insulinlike effects of vanadate on hepatic glycogen metabolism in nondiabetic and streptozotocin-induced diabetic rats. Diabetes 39: $821-827$ 